\title{
Calcium Supplement
}

National Cancer Institute

\section{Source}

National Cancer Institute. Calcium Supplement. NCI Thesaurus. Code C137864.

A dietary supplement containing the mineral calcium. 